\title{
TAXATION OF ESTATE AND TRUST INCOME UNDER THE 1954 CODE
}

\section{George Craven $\dagger$}

The rules for taxing income of estates and trusts are changed in many respects by the Internal Revenue Code of 1954, which makes the first important revision of such rules since the enactment of the Revenue Act of 1942. The revised rules are set forth in Part I of Subchapter J of Chapter 1.

With certain minor exceptions, discussed below, ${ }^{1}$ the new provisions are applicable to the calendar year 1954 and to fiscal years beginning after December 31, 1953 and ending after August 16, 1954. ${ }^{2}$ If an estate or trust made a final distribution of its assets and thus terminated in 1954 on or before August 16, presumably the 1939 Code would apply to its final year.

\section{General Statutory Plan}

The general rules are set forth in Subpart A of Part I, comprising Sections 641 to 643 . The 1954 law continues the prior general pattern of taxing estates and trusts in the same manner as individuals on net income, now termed taxable income, and the tax is payable by the fiduciary on such income. ${ }^{3}$ With certain exceptions, ${ }^{4}$ an estate or trust is allowed the same deductions allowed to individuals, and in addition a deduction is allowed for income required to be distributed currently or which is distributed currently. ${ }^{5}$

As in the prior law, the test of the amount of a distribution which is taxable to beneficiaries is the amount of the additional deduction allowed to the estate or trust. ${ }^{b}$ Some of the changes incorporated in the new statute are designed to remove complexities resulting from the 65-day and 12-month rules enacted in 1942,7 and to relieve beneficiaries

$\dagger$ A.B., L.L.B., Mercer University; member of Georgia, Florida, New York and Pennsylvania Bars.

1. See text at note 73 and note 81 infra.

2. INT. REv. CODE of $1954, \S 683$ (a). Except where otherwise specified, the statutory references below are to the Internal Revenue Code of 1954.

3. $\S 641(b)$.

4. $\S \S 642(b),(c),(i)$.

5. $\S \S 651,661$.

6. $\S \S 652(a), 662(a)$.

7. See text at note 69 infra. 
of tax on distributions of amounts which are not part of the taxable income of the estate or trust. ${ }^{8}$

The new law preserves the conduit theory of an estate or trust by providing that various classes of income received by the estate or trust shall retain their same character of taxable, tax-exempt or partially tax-exempt income in the hands of the beneficiaries. ${ }^{9}$ If all the income is distributable or distributed currently, the beneficiaries receive the full credit against their tax for foreign taxes, partially taxexempt interest, and dividends received; if part of the income is distributed and part retained by the estate or trust, the credits are apportioned ratably between the fiduciary and the beneficiaries. ${ }^{10}$

An estate in process of administration will continue to have a personal exemption of $\$ 600$, and a trust which may accumulate income will continue to have an exemption of $\$ 100$; the exemption of a distributable trust is increased from $\$ 100$ to $\$ 300$, which amount will be available as a deduction from capital gain, extraordinary dividends and other taxable income which is properly allocable to corpus. ${ }^{11}$ As under prior law, the 1954 law allows as a deduction any amount of the gross income, without limitation, which pursuant to the terms of the will or trust instrument is paid to or set aside for qualified charitable organizations or purposes. ${ }^{12}$ However, the 1954 statute provides that the charitable deduction is to be reduced by an allocable portion of tax-exempt interest and foreign income. ${ }^{13}$

The new statute continues the prior provision that amounts allowable as deductions for estate tax purposes as well as for income tax purposes (not including certain items of deductions in respect of a decedent which are allowable for both taxes) shall not be allowed as income tax deductions on the return of an estate unless a waiver is filed of the right to have such amounts allowed as estate tax deductions. ${ }^{14}$ The 1954 law, like the prior law, denies the standard deduction to an estate or trust. ${ }^{15}$

If the taxable year of a beneficiary is different from that of an estate or trust, the amount includible in the gross income of the beneficiary is based on the income of the estate or trust for its taxable

8. See discussion under the heading "Distributions Not Taxable to Beneficiaries Unless Made from Taxable Income" at p. 609 infra.

9. $\$ \$ 652(b), 662(b)$.

10. $\$ 642(a)$.

11. $\$ 642(\mathrm{~b})$.

12. $\S 642(\mathrm{c})$.

13. $\$ 643(\mathrm{a})$ (concluding 2 sentences).

14. $\$ 642(\mathrm{~g})$.

15. $\S 642(\mathrm{i}), 142(\mathrm{~b})(4)$. 
year ending within or with his taxable year. ${ }^{16}$ The prior law had a similar provision relating to distributable trusts ${ }^{17}$ but no such provision relating to estates or to trusts which may accumulate income.

\section{Deductions on Termination of Estate or Trust}

An important new provision in the 1954 Code states that if at the time of termination an estate or trust has a net operating loss carryover, a capital loss carryover or deductions for the final year in excess of gross income (exclusive of the deductions for the personal exemption and amounts paid to or set aside for charity), such amounts shall be allowed as deductions to the beneficiaries succeeding to the property of the estate or trust. ${ }^{18}$ This provision will enable beneficiaries to take deductions for items such as trustees' commissions and attorneys' fees paid from corpus which exceed income of the estate or trust and which under prior law were not available as deductions. ${ }^{19}$ In order to assure the right of the beneficiaries to such deductions, it seems advisable that there be a complete distribution of all assets of the estate or trust, so that there can be no question about whether it has terminated. ${ }^{20}$

The use of the words "capital loss carryover," which signify a loss carried over from one year to another, ${ }^{21}$ rather than the words "capital loss," raises the question whether the beneficiaries of a terminated estate or trust may take a deduction for a capital loss in the same year in which it is sustained by the estate or trust or whether such loss will be available to the beneficiaries only as a capital loss carryover in subsequent years. The report of the Senate Finance Committee says that this provision makes available to beneficiaries "any unused capital loss," 22 indicating that the word "carryover" was used inadvertently in the statute. It is to be hoped that this point will be clarified by the regulations or by a statutory amendment.

16. $\$ \$ 652(c), 662(c)$.

17. Int. Rev. Code of $1939, \S 164$, as amended, 56 Stat. 810 (1942).

18. $\S 642(\mathrm{~h})$.

19. See H.R. Rep. No. 1337, $83 d$ Cong., 2d Sess. A201 (1954); Sen. Rep. No. 1622, 83d Cong., 2d Sess. 343 (1954); McDonald, Deduction of Attorneys' Fees for Federal Income Tax Purposes, 103 U. of PA. L. Rev. 168, 202-03 (1954).

20. See Sen. Rep. No. 1622, $83 d$ Cong., 2d Sess. 340 (1954). On the question of when a trust is considered terminated, see Craven, Capital Gains and Losses Affecting Estates and Trusts, 26 TEMP. L.Q. 240, 246 (1953); Note, Trust Administration Upon Termination, 32 CHI-Kent Rev. 307 (1954).

21. See $\S 1212$.

22. Sen. Rep. No. 1622, 83d Cong., 2d Sess. 343 (1954). 


\section{Limitation on Amounts TaXable to Beneficiaries}

A considerable amount of confusion resulted from the use in the 1939 Code $^{23}$ of the word "income," rather than "gross income" or "net income," to describe amounts which were deductible by the fiduciary and taxable to beneficiaries. The word "income" was construed in some instances to mean income for purposes of fiduciary accounting under state law. ${ }^{24}$ The 1954 Code eliminates this problem by using the term "income" to mean amounts which are income under the will or trust instrument and local law, and the terms "gross income," "taxable income," "distributable net income" and "undistributed net income" to describe amounts which are taxable under the income tax statute. ${ }^{25}$

The amount which is properly distributable or distributed to an income beneficiary is based on income under state law, but the amount which is deductible by the fiduciary and taxable to the beneficiary is based on distributable net income as defined in the income tax statute. ${ }^{26}$ As is shown below, the total amounts taxable to beneficiaries in any year cannot in any event exceed the distributable net income of the estate or trust for that year. Taxable income under the 1954 Code ${ }^{27}$ substantially corresponds to net income under the 1939 Code.

\section{Definition of Distributable Net Income}

Distributable net income is defined in the 1954 statute to mean the taxable income of the estate or trust computed with the following modifications : ${ }^{28}$

The amount computed as taxable income is increased by the following items:

(1) the deduction for the distributions to beneficiaries, called the additional deduction;

(2) the personal exemption;

(3) capital losses, except to the extent that such losses are taken into account in determining the amount of capital gain which is dis-

23. Int. Rev. Code of 1939, $\S \S 162$ (b), (c), as amended, 56 Stat. 809 (1942).

24. See, e.g., Rogers' Estate v. Commissioner, 143 F.2d 695 (2d Cir,), cert. denied, 323 U.S. 780 (1944) ; Weigel v. Commissioner, 96 F.2d 387 (7th Cir. 1938); Chambers v. Commissioner, 33 B.T.A. 1125 (1936).

25. $\S 643(\mathrm{~b})$.

26. See Sew. Rep. No. 1622, $83 d$ Cong., 2d Sess. 346-47 (1954).

27. $\$ 63$.

28. $\$ 643(a)$. 
tributable or distributed to beneficiaries. ${ }^{29}$ The deduction for $50 \%$ of the excess of net long-term capital gain over net short-term capital loss $^{30}$ is not taken into account in computing taxable income for determining distributable net income, thereby increasing the amount of distributable net income;

(4) tax-exempt interest, reduced by expenses not allowable in computing taxable income which are allocable to such interest and by the portion of such interest which is paid or set aside for charitable purposes;

(5) in the case of a foreign trust, ${ }^{31}$ amounts of gross income from foreign sources, reduced by expenses not allowable in computing taxable income which are allocable to such foreign income and by the portion of such foreign income which is paid to or set aside for charitable purposes; ${ }^{32}$ and

(6) the amount of the dividend exclusion ( $\$ 50)$.

The amount computed as taxable income is decreased by the following items:

(1) capital gains, to the extent that such gains are allocated to corpus and are not either (a) paid, credited or required to be distributed to beneficiaries currently, or (b) paid or set aside for charitable purposes; and

(2) in the case of distributable trusts, extraordinary dividends or taxable stock dividends which the fiduciary, acting in good faith, determines are allocable to corpus under the will or trust instrument and applicable state law.

The deduction for amounts paid to or set aside for charitable purposes is based on gross income of the estate or trust. ${ }^{33}$ Therefore, this deduction is taken along with other deductions in arriving at taxable income, which forms the basis for computing distributable net income. In determining the amount of the charitable deduction, a proportionate part of tax-exempt income must be allocated to the charity, and the deduction is limited to the amount allocated from gross income. ${ }^{34}$

29. The capital loss may be carried forward under $\S 1212$.

30. See $\S 1202$.

31. Although the Code uses the word "trust," $\$ 643(a)(6)$, foreign income is exempt from tax only if received by a non-resident alien beneficiary. See $\$ 872(\mathrm{a})$.

32. Items (4) and (5), which are nontaxable income, are added to taxable income merely for the purpose of allocating various classes of income among the fiduciary and various beneficiaries. However, they retain their character of nontaxable income in the hands of the beneficiaries and thus remain free of tax.

33. $\S 642$ (c).

34. $\$ 643$ (a) (concluding 2 sentences). 
It is important to note that in arriving at distributable net income, which limits the amount taxable to beneficiaries, the only amounts of gross income allocated to principal which are excluded are capital gains and, in the case of distributable trusts (but not in the case of estates or of trusts which may accumulate income), extraordinary dividends and taxable stock dividends which in good faith are credited to principal. The statute does not permit the exclusion of other undistributed items of income allocable to principal, such as reserves set aside for amortization of the cost of improvements to real property where the amounts set aside exceed the allowable deduction for depreciation, or amounts, other than capital gains, which had accrued as income to a decedent at the time of his death and which are includible in income of the estate. Presumably, those amounts were omitted on practical grounds.

The report of the Senate Finance Committee points out that since capital gains are not excluded from distributable net income in cases where they are paid to a beneficiary during the taxable year, capital gains which are paid to a beneficiary in the year of termination of a trust will be taxable to the beneficiary. ${ }^{35}$ This would be equally true of capital gains paid to a beneficiary of an estate. In view of that rule, it may be important to determine whether amounts of principal paid by an executor to legatees, from a commingled bank account which includes capital gain, include any of such capital gain or whether the amounts paid are wholly principal other than capital gain. In the absence of a statutory provision for determining when capital gains are to be considered distributed, the determination apparently must be made by entries on the books of the fiduciary. ${ }^{36}$ This point should be clarified by regulations.

The only deductions the amounts of which are added to taxable income in arriving at distributable net income are those allowed for distributions, capital losses and the personal exemption. Therefore, in arriving at distributable net income, taxable income will be computed by taking other deductions chargeable to principal, such as trustees' commissions and attorneys' fees allocable to principal, which under prior law were not allowable in arriving at income taxable to beneficiaries and which were wasted unless there was income chargeable to corpus from which they might be deducted. ${ }^{37}$ One odd result of this rule is that if there are capital gains or extraordinary dividends which are credited to principal, but which are excluded from distribut-

35. Sen. Rep. No. 1622, 83d Cong., 2d Sess. 343-44 (1954).

36. See Garrett v. Commissioner, 45 B.T.A. 848 (1941).

37. See H.R. Rep. No. 1337, 83d Cong., 2d Sess. A197 (1954). 
able net income, deductions chargeable to corpus will not be allowable in reduction of that income but will inure solely to the benefit of the income beneficiaries, except to the extent that they exceed amounts of taxable income which are includible in distributable net income. It would seem more equitable to allow such deductions first from income credited to principal and to the extent of any excess as deductions in arriving at distributable net income.

\section{Distributable Trusts}

Trusts which are required to distribute all their income currently are dealt with exclusively in Subpart B of Part I, comprising Sections 651 and $652 .^{38}$ These trusts are referred to in the report of the House Ways and Means Committee as "simple trusts," to distinguish them from "complex trusts," a term used in the Committee report to describe decedent's estates, trusts which are not required to distribute all their income currently, trusts which make distributions of principal and trusts which pay or set aside amounts for charitable purposes. ${ }^{39}$

Distributable trusts are taxed generally in the same way as under prior law. A deduction is allowed to the trust for amounts of income required to be distributed currently, and those amounts are taxed to beneficiaries whether distributed or not. ${ }^{40}$ However, the amounts deductible by the trust and taxable to the beneficiaries are limited to the distributable net income of the trust for the taxable year. The statute states that for the purpose of determining the amount deductible by the trust, the computation of distributable net income shall not include items of income which are not included in the gross income of the trust and deductions allocable thereto. ${ }^{41}$ This means that for this purpose, distributable net income is computed without including tax-exempt interest, foreign income in certain cases and the amount of dividends excluded from gross income. The effect of this provision is to prevent the trust from obtaining a deduction for amounts not included in its gross income.

If the amount of income (under state law) to be distributed currently exceeds the distributable net income of the trust, the amount

38. In any year in which a trustee makes distributions of principal to a remainderman, the trust will be treated as a complex trust, $\$ 651$ (a). This may not necessarily include the year in which the income beneficiary dies if no distribution of principal is made in that year.

39. Sen. ReP. No. 1622, 83d Cong., 2d Sess. 61, 62 (1954). The so-called complex trusts are governed by Subpart $C$ comprising $\$ \$ 661$ and 662 which are discussed under the heading "Estates and Other Trusts" at p. 611 infra. The terms "simple trusts" and "complex trusts" are not used in the statute or in the report of the Senate Finance Committee.

40 . $\$ 851,652$.

41. $\S 651(\mathrm{~b})$. 
included in the gross income of each beneficiary is an amount which bears the same ratio to distributable net income as the amount of income (under state law) distributable to such beneficiary bears to the total distributable income (under state law) of the trust. ${ }^{42}$

\section{Distributions Not Taxable to Beneficiaries Unless Made from Taxable Income}

A result of the provision limiting the amount taxable to beneficiaries to the distributable net income of the trust is that amounts distributed as income under state law which are not part of the gross income of the trust will not be taxed as income to beneficiaries. This provision nullifies the rules of Johnston $v$. Helvering ${ }^{43}$ and $\mathrm{McCul}$ lough $v$. Commissioner, ${ }^{44}$ which dealt with distributions of amounts considered income under state law which were not part of the gross income of the trust. ${ }^{45}$ In the Johnston case, a trustee foreclosed a mortgage on real estate and in a later year sold the property at a loss and, under the applicable rule of state law, ${ }^{46}$ allocated part of the proceeds of sale to the income beneficiaries. It was held that since the amounts received by the beneficiaries were income under state law, they were includible in gross income of the beneficiaries for income tax purposes. In the $M c$ Cullough case, a trustee received a non-taxable stock dividend of common-on-common and allocated a part of the dividend shares to the income beneficiary under state law. It was held that the dividend stock reached the income beneficiary as taxable income and that his basis was the fair market value of the stock at the time of distribution and not merely a proportionate part of the trustee's basis for the original stock.

This new rule, limiting amounts taxable to beneficiaries to distributable net income of the trust for the taxable year, is equally applicable to estates and to trusts which may accumulate income. ${ }^{47}$

\section{Character of Amounts of Income: Allocation of Deductions}

Items of income of various classes which are included in distributable net income will preserve their same character in the hands

42. $\$ 652(a)$.

43. 141 F.2d 208 (2d Cir.), cert. denied, 323 U.S. 715 (1944).

44. 153 F.2d 345 (2d Cir. 1946).

45. See H.R. Rep. No. 1337, 83d Cong., 2d Sess. A197 (1954) ; Sen. Rep. No. 1622, 83d Cong., 2d Sess. 346-47 (1954).

46. See, e.g., Nirdlinger's Estate, $327 \mathrm{~Pa} .171,193$ Atl. 30 (1937).

47. $\S 662(a)$. 
of beneficiaries. The statute provides that unless the trust instrument specifically allocates different classes of income to different beneficiaries, amounts distributed to beneficiaries will be treated as consisting of a ratable part of each class of income entering into the computation of distributable net income, ${ }^{48}$ so that each beneficiary will exclude from gross income his ratable share of tax-exempt income and will take credit for an allocable portion of dividends received, partially taxable income and foreign taxes. It is implicit in the statute that it is permissible to provide in the will or other trust instrument that certain beneficiaries shall receive fully taxable income and that others shall receive partially taxable, tax-exempt or foreign income.

The statute provides further that in applying the rule which apportions various items of income among beneficiaries, the items of deduction entering into the computation of distributable net income shall be allocated among the items of distributable net income in accordance with regulations prescribed by the Secretary of the Treasury or his delegate. ${ }^{49}$ There is a similar provision in the statute relating to estates and to trusts which may accumulate income. ${ }^{50}$ The meaning of this provision is not clear. With the exception of the requirement that nonbusiness expenses be allocated between taxable and non-taxable income, ${ }^{51}$ there was no requirement in the prior law that various items of deductions of an estate or trust be allocated among various classes of income. Under prior law, as in the case of individuals, expenses of an estate or trust were charged first againșt income which enjoyed no tax privilege, such as fully taxable interest, and only the excess deductions served to reduce income having tax privileges, such as partially taxable interest. The new statute appears to empower the Treasury Department to prescribe by regulations that the prior rule shall continue in force and that for this purpose an estate or trust shall be treated in the same way as an individual.

If the Treasury Department should issue regulations requiring that each item of deduction be allocated among various classes of income of an estate or trust, the resulting burden to corporate fiduciaries would be very great, without producing any substantial amount of revenue. It has been estimated by representatives of Philadelphia trust companies that if such requirement is made, the time consumed in preparing fiduciary returns will be more than doubled. It is to be

48. $\$ 652(\mathrm{~b})$.

49. Ibid.

50. $\S 662(\mathrm{~b})$. (1942).

51. Int. Rev. Code of 1939, $\$ 23$ (a) (2), 24(a) (5), as amended, 56 Stat. 819 
hoped that no such regulation will be issued ${ }^{52}$ and that if such regulation is issued, Congress will come promptly to the rescue of fiduciaries by amending the statute so as to make it clear that no such allocation is required.

\section{Estates and Other Trusts}

The provisions relating to decedents' estates and to trusts which may accumulate income, pay amounts from principal or set aside income for charitable purposes are found in Subpart C of Part I, comprising Sections 661 to 663 . They follow in general the rules relating to distributable trusts. Amounts which are taxable to beneficiaries are limited to the distributable net income of the estate or trust, ${ }^{53}$ which is the same as in the case of a distributable trust except that extraordinary dividends and taxable stock dividends are included in income. $^{54}$ If part of the distributable net income is distributed to beneficiaries and part retained by the estate, various classes of income are allocated ratably to the estate and beneficiaries. ${ }^{55}$

In determining the distributable net income allocable to beneficiaries, the beneficiaries are divided into two groups or tiers, and an order of priority is established. The distributable net income is first reduced by amounts of income required to be distributed currently, including amounts required to be distributed currently which may be paid from income or corpus but which in fact are paid from income for the taxable year. ${ }^{56}$ The beneficiaries of the required current distributions constitute the first tier, and the amounts of the required current distributions are allocated among and included in the income of those beneficiaries in the same way as income of a fully distributable trust. ${ }^{57}$ The second tier of beneficiaries consists of those to whom any other amounts are paid, credited or to be distributed during the taxable year. The amounts taxable to beneficiaries in this tier are limited to distributable net income of the estate or trust reduced by the distributable net income payable to those in the first tier, and are allocated in the same way as in the case of distributable trusts. ${ }^{58}$ Therefore, if the total amounts distributable to beneficiaries of the first tier

52. The instruction sheet for the fiduciary return, Form 1041, does not require such allocation, and the writer understands that no such requirement will be made in the regulations.

53. $\S 662(a)$.

54. $\S 643(2)(4)$.

55. $\S 661(\mathrm{~b})$.

56. $\S 661(\mathrm{a})(1)$.

57. $\S 662(\mathrm{a})(1)$.

58. $\S 662(a)(2)$. 
exceed the distributable net income for the taxable year, second tier beneficiaries are not taxed on current income. ${ }^{59}$

In computing distributable net income for the purpose of allocating various classes of income to beneficiaries in the first tier, the deduction for amounts of gross income paid to or set aside for charitable purposes is allowed only to the extent that such amounts are paid or set aside from income of the estate or trust for the taxable year. ${ }^{60}$ For example, assume that the trust instrument provides that one-half of the income shall be distributed each year to $A$, that in the trustee's discretion all or any part of the balance may be accumulated or distributed to $B$ or to designated charitable organizations and that income accumulated in one year may be distributed in a subsequent year to $B$ or to the designated charitable organizations; assume further that the trust for the taxable year has $\$ 10,000$ of taxable interest, $\$ 8,000$ of dividends for which the $4 \%$ credit is allowable and $\$ 5,000$ of taxexempt interest, and that the trustee distributes $\$ 11,500$ to $A$ and $\$ 20,000$ to charity $X$ (consisting of $\$ 11,500$ of current income and $\$ 8,500$ of income accumulated in a prior year). The charitable deduction will be $\$ 11,500$, and not the $\$ 20,000$ actually distributed to the charity; $A$ will be deemed to receive $\$ 5,000$ of taxable interest, $\$ 4,000$ of dividends for which the $4 \%$ credit is allowable and $\$ 2,500$ of tax-exempt interest.

Beneficiaries who fall into the second tier include those entitled to receive annuities or other amounts payable out of principal. The statute treats as income distributions, subject to the distributable net income limitation, all amounts paid or to be distributed from either income or principal except lump sum gifts or bequests which meet the tests described below. ${ }^{61}$ The 1954 Code thus continues the provisions of the prior law, ${ }^{62}$ enacted in 1942, designed to change the rule of Burnet $v$. Whitehouse, ${ }^{63}$ which held that annual payments which might be satisfied from principal were exempt from tax to beneficiaries as gifts or bequests, even though paid wholly from income.

If the trust instrument should provide for accumulation of income and the payment of annual amounts from principal to individual beneficiaries, the annual payments would be treated as income to the beneficiaries in an amount not in excess of the distributable net income of

59. Ibid.

60. $\S 662$ (b). See Sen. REp. No. 1622, 83d Cong., 2d Sess. 350 (1954).

61. $\$ 662(a)(2), 663$. See text following note 64 infra.

62. Int. Rev. Code of $1939, \S 162$ (d), added by 56 STAT. 809 (1942), as amended, 58 STAT. 50 (1944).

63. 283 U.S. 148 (1931). 
the trust. On the other hand, if trust income is accumulated for the benefit of individuals and annual payments are made from principal to charitable organizations, the income each year will be taxed to the trust, subject to the application of the five-year throwback..$^{64}$

\section{Lump Sum Bequests Not Taxed as Income. Treatment of Residuary Bequests}

The 1954 statute excepts from amounts which are treated as income distributions an amount properly paid or credited under the governing instrument as a "gift or bequest of a specific sum of money or of specific property" which (1) is paid all at once or in not more than three installments and (2) cannot be paid or credited wholly from income. ${ }^{65}$ An amount paid on account of a specific bequest or devise ${ }^{66}$ is taxable as income to the legatee or devisee if it is paid in more than three installments or if the will specifies that it is to be paid from income. $^{67}$

However, through what may have been an oversight in drafting the statute, this exception does not extend to an amount paid in satisfaction of a general or residuary bequest or devise, or an amount of principal distributed under the intestacy laws. The failure to provide an exception for distributions of such amounts of principal means that if the statute is construed literally, any principal distribution of an estate, other than amounts paid on account of a specific bequest or devise, will be treated as a distribution of income. This will undoubtedly result in serious complications in the administration of an estate and in many instances will produce unintended and inequitable results.

For example, suppose that a testator leaves a residuary estate of $\$ 200,000$, of which one-half is left outright to $A$ and one-half is left in trust to pay the income to $B$ for life; that the distributable net income of the estate for the taxable year is $\$ 10,000$; that one-half of such income is paid to $A$ and one-half is paid to the trust and thus becomes distributable to $B$; and that a principal distribution of $\$ 40,000$ is made to $A$. The total distributions which will be considered distributions of income amount to $\$ 50,000$, of which $A$ receives $\$ 45,000$ or $9 / 10$ and $B$ receives $\$ 5,000$ or $1 / 10$. $A$ will be taxable on $9 / 10$ of the distributable net income or $\$ 9,000$, and $B$ will be taxable on only $1 / 10$ or $\$ 1,000 .^{88}$ If, on the other hand, the income is distributed in the same

64. See discussion under the heading "Five-Year Throwback" at p. 616 infra.

65. $\$ 663(a)$.

66. Although the statutory language does not include the word "devise," the word "gift" should be broad enough to include devises.

67. See SEn. Rep. No. 1622, 83d Cong., 2d Sess. 353-54 (1954).

68. $\$ 662(a)(2)$. 
way but the $\$ 40,000$ of principal is paid to the trust for $B$ rather than to $A$, the trust will be deemed to receive $\$ 9,000$ of income and $A \$ 1,000$, and of the $\$ 9,000$, presumably $\$ 5,000$ will be considered distributable and taxable to $B$ and the remaining $\$ 4,000$ will be taxable to the trust.

Many other examples could be given of curious and probably unintended results which are brought about by this statutory quirk. There is a serious question about the constitutionality of an income tax statute which taxes to a beneficiary receiving principal an amount of income in excess of an amount which may inure to his benefit. This provision requires prompt remedial action by Congress in order to eliminate any requirement that amounts of principal distributed by an estate in process of administration shall be treated as distributions of income.

\section{5-Day and 12-Month Rules Abolished}

With the exceptions discussed below, the statute relating to estates and to trusts which may accumulate income abolishes the 65-day and 12-month rules of the prior statute, ${ }^{69}$ enacted in 1942 to provide for taxing to beneficiaries amounts received by an estate or trust in one year and distributed to beneficiaries in another. Prior to the 1942 act, such amounts were held taxable to the estate or trust in the year of receipt and exempt from tax to the beneficiaries in the year of distribution. ${ }^{70}$ The 65 -day rule provided that if within the first 65 days of a taxable year income of an estate or trust for a prior period became payable, such income (to the extent not in excess of the income of the estate or trust for the last 12 months of the prior period) should be deemed distributed on the last day of the preceding year. The 12month rule provided that if on a date more than 65 days after the beginning of the taxable year income of an estate or trust became payable, such income should be considered a distribution of income of the taxable year to the extent of the income of the estate or trust for the last 12 months of the period in which the income was received by the estate or trust. The new statute provides in substance that a distribution shall be deemed a distribution of current income to the extent of distributable net income of the estate or trust for the taxable year. ${ }^{71}$ Therefore, it is immaterial whether a distribution is made from current or prior year's income and how much income is on hand when the distribution is made.

69. Int. Rev. Code of $1939, \S 162$ (d).

70. See Graham v. Miller, 137 F.2d 507 (3d Cir. 1943); Commissioner v. Dean, 102 F.2d 699 (10th Cir. 1939); G.C.M. 21799, 1940-1 CuM. Buts. 159.

71. $\S 662(a)$. 
For example, assume that the distributable net income of an estate in process of administration is $\$ 10,000$ for 1954 and $\$ 10,000$ for 1955, and that the estate makes no income distribution in 1954 but distributes $\$ 10,000$ of income on January 2, 1955. The distribution will be considered a distribution of 1955 income and will be taxed to the beneficiaries as such. However, if the distributable net income of the estate for 1955 should be only $\$ 8,000$, only that amount of income would be taxed as income to the beneficiaries.

As has been pointed out, the provisions of the 1954 Code apply to taxable years of estates or trusts beginning after December 31, 1953 and ending after August 16, 1954. ${ }^{\mathbf{2}}$ However, the 1954 law preserves the 65-day rule of the 1939 Code in the case of distributions, made during the first 65 days of the first taxable year governed by the new law, which under the prior law would be deemed made on the last day of the preceding year. ${ }^{73}$ Therefore, such distributions will be deductible by the estate or trust and taxable to the beneficiaries as income of the prior year.

The new statute preserves the 65-day rule for trusts which meet certain requirements, but not for estates. It provides that an amount paid by a trust within the first 65 days of its taxable year shall be considered paid on the last day of the preceding year if (1) the trust was in existence prior to January 1,1954, (2) under the terms of the trust instrument the trust may not distribute in any taxable year amounts in excess of its income for the preceding year, and (3) the fiduciary makes an election under the statute and regulations to have such rule apply. If the fiduciary makes such an election with respect to any taxable year, the rule is applicable to amounts paid within the first 65 days of all subsequent years. ${ }^{74}$

It will no longer be possible for an executor to make distributions in the first 65 days of the succeeding year and have them treated as current distributions. The distributions, in order to be deductible by the estate and taxable to the beneficiaries, must be made by the end of the taxable year of the estate. Conversely, by withholding a distribution until the year has ended, the executor will prevent it from being taxed currently to a beneficiary, although it may be taxed to the beneficiary

72. $\S 683(a)$.

73. $\$ 683(\mathrm{~b})$.

74. $\S 663(\mathrm{~b})$. The writer believes that the only effect of the exercise of such election would be to tax to beneficiaries and not to the trust the income of a trust for the calendar year 1954 (or a fiscal year beginning in 1954 and ending after August 16, 1954) which was not distributed in that year but was distributed in the first 65 days of the following year. If the election were not exercised, the income for 1954 would be taxed to the trust, but in 1955 and subsequent years, when income of a prior year is distributed, it would be treated as a distribution of income in the year of distribution. 
as income for the year of distribution. This will likewise be true of trusts other than those which meet the requirements stated in the preceding paragraph.

\section{Separate Shares Treated as Separate Trusts}

The new statute provides that for the sole purpose of determining the amount of distributable net income which is taxable to a beneficiary under the rules relating to so-called complex trusts, if a single trust has more than one beneficiary, substantially separate and independent shares of different beneficiaries are to be treated as separate trusts. This rule is to be applied under tests prescribed by the regulations. ${ }^{75}$ The report of the Senate Finance Committee states that the effect of this provision is to prevent a beneficiary from being taxed on a distribution which is made from corpus but which, would, except for this provision, be treated as a taxable distribution because trust income is being accumulated for another beneficiary. ${ }^{76}$ The division of the trust into separate shares or trusts will prevent the beneficiary receiving corpus from being taxed on an amount in excess of the distributable net income of the trust of his share.

Unfortunately, the separate share rule applies only to trusts and not to estates. One solution of the problem resulting from treating distributions of non-specific principal of an estate as distributions of income ${ }^{77}$ would be to extend the separate share rule to an estate. If this were done, a beneficiary receiving a distribution of principal would not be taxable on income in excess of the income from his share of the estate.

\section{FIVE-YeAR ThrowBack}

The 1954 statute in Subpart D of Part I, comprising Sections 665 to 668 , makes a complete innovation by enacting a five-year throwback rule for taxing to beneficiaries distributions of trust income which exceed the distributable net income of the trust for the taxable year. Those provisions are based in part on a statutory draft prepared by the American Law Institute, although that draft limits the period of the throwback to two years. ${ }^{78}$ The purpose of the new rule is to prevent the use of income accumulations in a trust to obtain the benefit of tax rates lower than those which would be applicable if the income were

75. $\$ 663(\mathrm{c})$.

76. Sen. Rep. No. 1622, 83d Cong., $2 d$ Sess. 355 (1954).

77. See text following note 67 supra.

78. ALI Fed. Income Tax Stat. \$X841 (Feb. 1954 Draft). 
received each year by beneficiaries. ${ }^{79}$ It is aimed primarily at the creation of multiple trusts with income accumulations for substantially the same beneficiaries.

The throwback rule is not applicable to an estate in process of administration and is not applicable to the following amounts of trust income: ${ }^{80}$

(1) amounts paid or distributable to a beneficiary as income accumulated before his birth or during his minority; needs;

(2) amounts paid to a beneficiary to meet his emergency

(3) amounts paid to a beneficiary at a specified age if (a) the total number of such distributions to him cannot exceed four, (b) there is a period of at least four years between each such distribution, and (c) on January 1, 1954 such distributions were required by the specific terms of the governing instrument; and

(4) amounts paid to a beneficiary as a final distribution of the trust if the distribution is made more than nine years after the date of the last transfer to the trust.

The throwback rule applies to income accumulated in taxable years beginning after December $31,1953 .{ }^{81}$ It has no application to trust accumulations under the laws of states, such as New York, where income may be accumulated for an individual only during minority. How- · ever, it would apply in Pennsylvania to trust income accumulated during the life of the grantor and beyond the minority of a beneficiary. Likewise, it would apply to accumulations governed by the law of a state having the common law rule against accumulations if the accumulation is not for the benefit of a minor or unborn persons and does not fall within any of the other exceptions specified above.

The distributions to which the throwback rule applies are distributions made during the taxable year of amounts which are treated as income distributions under the rules relating to complex trusts. The rule comes into play in any year in which those distributions exceed by more than $\$ 2,000$ the distributable net income of a trust for that year reduced by income distributions which are required to be made currently. ${ }^{82}$

Where the excess distributions amount to more than $\$ 2,000$, the entire amount of the excess is thrown back in inverse order to the five

79. See H.R. Rep. No. 1337, 83d Cong., 2d Sess. 62 (1954).

80. $\S 665(\mathrm{~b})$.

81. $\S 666(a)$. It does not apply to distributions after that date of income accumulated prior to that date.

82. $\S 665(\mathrm{~b})$. 
taxable years preceding the year of distribution and is treated successively as a distribution on the last day of each of those years to the extent that such amount exceeds the total undistributed net income for any taxable years intervening between the year of actual distribution and the preceding year to which the excess is thrown back. ${ }^{83}$ Whether or not there is any undistributed net income for any one or more of the five preceding years to which the excess distributions are thrown back, such excess distributions cannot in any event be deemed made for any year more than five years prior to the year of the actual distribution. Undistributed net income of a trust for any year is defined to mean the amount by which the distributable net income for that year exceeds (1) the deduction for that year for income distributions and (2) the income tax of the trust for that year. ${ }^{84}$

If the amount thrown back to any preceding year is equal to the entire amount of undistributed net income of the trust for such year, the beneficiary is given credit for the tax paid by the trust on such undistributed net income; if the amount thrown back is less than the total undistributed net income of the trust for the preceding year, the beneficiary is given credit for a ratable portion of the tax paid by the trust on undistributed net income. The amount of the tax so credited to the beneficiary is in turn treated as an additional income distribution to the beneficiary for the year for which the tax was paid. ${ }^{85}$

For example, suppose that a trust accumulates in each of the years 1954 to 1959 , inclusive, $\$ 4,000$ of taxable income and that it pays $\$ 800$ in income tax each year, leaving undistributed net income of $\$ 3,200$ each year for the six-year period. Assume further that in 1960, in addition to distributing all its distributable net income for that year, it distributes to a beneficiary the total accumulated income of $\$ 19,200$. Income of $\$ 3,200$ will be deemed distributed to the beneficiary on the last day of each of the years 1955 to 1959 , inclusive, a total of $\$ 16,000$. In addition, the total taxes of $\$ 4,000$ paid by the trust on undistributed net income for such five years will be deemed distributed in equal amounts in such years and will be included in the beneficiary's income, making total income distributions of $\$ 20,000$, and the beneficiary will be given credit for such taxes. Since the accumulation in 1954 extends beyond the five-year period, it will be disregarded. The rule is more complicated where only a part of the income of the trust for a prior year is deemed distributed to the beneficiary. ${ }^{86}$

83. $\S 666(a)$.

84. $\S 665(a)$.

85. $\$ 8668(b), 666(b),(c)$.

86. It is provided in $\S 668(\mathrm{c})$ that if only a portion of the undistributed net income of the trust for prior year is deemed distributed to the beneficiary in the 


\section{Method of Taxing Excess Distributions}

The total of the amount deemed distributed to the beneficiary in prior years is included in the income of the beneficiary for the year in which the distribution is actually made to him. The income is included in the income of the beneficiary to the same extent that such income would have been includible if distributed on the last day of the year of accumulation. ${ }^{87}$ The various items of accumulated income thus retain the same character in the hands of the beneficiary which they had to the trust. However, the amount of tax payable by the beneficiary on such income for the year of distribution cannot be greater than the tax which would have been payable by him if the distributions had been made to him in the respective preceding years in which they are deemed made. ${ }^{88}$ This limitation will require a computation similar to that required in the case of compensation from employment covering a period of more than 36 months ${ }^{80}$ to determine whether the beneficiary's tax as so computed is less than the tax computed by including the entire amount of the excess distributions in his income in the year in which actually received.

It will no doubt be found in many instances, where the beneficiary had little or no income in the five-year period during which the income was accumulated, that the beneficiary's tax on the accumulated income is less than that of the trust. However, the application of the throwback rule cannot in any event result in a tax saving, as the statute expressly denies a refund of tax paid by the trust on accumulated income..$^{90}$

\section{Avoidance of Throwback Rule}

The application of the throwback rule may be avoided in a state having the common-law rule against accumulations by providing that after the accumulation period the trust income shall be distributed each year for five years and that the accumulated income shall be distributed at the end of the five-year period. This plan may be followed also in Pennsylvania where the accumulation period of an inter vivos trust is

prior year, the beneficiary's income shall be increased by a pro rata portion of the income tax paid by the trust on the prior year's undistributed net income. However, $\S 668$ (b) provides that the beneficiary shall receive credit against his tax for the portion of the tax which would not have been payable by the trust for the prior year if the amount deemed distributed to the beneficiary in such year had in fact been distributed. This will result in the beneficiary's receiving credit for tax of the trust in excess of the amount of tax which is included in his income. See Kamin, Surrey \& Warren, The Internal Revenue Code of 1954: Trusts, Estates and Beneficiaries, 54 CoL. L. Rev. 1237, 1252 (1954).

87. $\S 668(a)$.

88. Ibid.

89. $\$ 1301$.

90. See $\S 667$. 
measured by the life of the grantor. Since the trust would have no undistributed net income during any of the five years preceding the year of distribution, none of the accumulated income in excess of the trust income for the year of distribution would be taxable to the beneficiaries.

Also, the application of the throwback rule may be avoided by providing for distribution of the accumulated income at the time of termination of the trust, as a final distribution, more than nine years after the creation of the trust. ${ }^{91}$ The throwback rule will be avoided in such case only if no additional transfers are made to the trust within nine years of its termination. However, as will be seen in the discussion of the statute taxing the grantor as substantial owner of trust income, ${ }^{92}$ if the principal of the trust fund is to revert to the grantor on termination, the trust must be created for a period of at least ten years to prevent the income from being taxed to the grantor.

\section{Criticism of Throwback Rule}

It is claimed by Treasury representatives that the throwback rule is necessary in order to prevent tax avoidance through the accumulation of income. No estimate has been published of the amount of revenue which these statutory provisions are designed to produce, and it may be that it is impossible to make such an estimate. In the absence of this rule, the accumulated income would be taxed each year to the trust, with an exemption of $\$ 100$; it is difficult to believe that the loss of revenue through income accumulations in trusts is sufficiently great to justify encumbering the income tax law with such intricate provisions.

The burden of attempting to apply the rule, like other burdens imposed by the 1954 statute, falls on the fiduciary and not on the beneficiaries. If a trust has various classes of income during a five-year period, some of which is distributed and some accumulated, it will involve a great amount of the fiduciary's time to ascertain, for each beneficiary to whom accumulated income is distributed, how much of each class of income and how much of the tax paid by the fiduciary in each of the five years is allocable to that beneficiary's share of accumulated income. The complications surrounding the application of the rule and the computation of the tax of the beneficiary cause one to wonder whether the cure is not worse than the disease. The throwback rule seems especially out of place in a statute designed to simplify the income tax laws.

91. $\S 665$ (b) (4).

92. See text at and following note 100 infra. 
It is to be hoped that after further consideration, Congress will decide that the throwback rule has no place in the income tax statute and should be repealed. However, if it is decided to retain this rule, the burden which it imposes would be softened by limiting its aplication to income accumulated during a period of two years prior to the year of distribution, as was proposed in the American Law Institute draft.

\section{Grantors and Others Treated as Substantial Owners}

The provisions of the 1954 Code taxing to grantors and others as substantial owners trust income not received by them are found in Subpart E of Part I of Subchapter J, comprising Sections 671 to 678 . They include new statutory provisions taxing trust income to the grantor under the principle of substantial ownership, a reenactment, with certain changes, of provisions of the prior law taxing trust income to the grantor because of a power to revoke or because trust income is or may be held or applied for the grantor's benefit, and new statutory provisions taxing trust income to a person other than the grantor because of a power to receive principal or income.

The 1954 statute states that no trust income may be taxed to the grantor or any other person solely on the grounds of dominion and control under any provision of the income taxe statute other than this subpart. $^{93}$

\section{Grantor Treated as Substantial Owener}

The rules for taxing income to the grantor under the principle of substantial ownership stem from the decision in Helvering $v$. Clifford, ${ }^{94}$ where the taxpayer created a trust for the benefit of his wife with himself as trustee for a period of five years, at the end of which period the trust corpus was to revert to the grantor. Although there was no provision of the statute taxing the trust income to the grantor, it was held that the grantor retained such dominion and control over the property during the short trust term that he was in substance the owner of the trust property for income tax purposes, and the income was taxable to him under the statutory definition of gross income. ${ }^{95}$

There was a vast amount of litigation resulting from efforts to apply the rule of the Clifford case to varying incidents of ownership over trust property and income. Regulations which have been in force

93. § 671. See SEn. Rep. No. 1622, 83d Cong., 2d Sess. 365 (1954).

94. 309 U.S. 331 (1940).

95. Revenue Act of 1934, §22(a), 48 Stat. 686 (1934). 
under the prior statute since $1946^{96}$ set forth detailed rules for determining when the grantor of a trust is to be regarded as substantial owner of the trust property or income. Certain provisions of the regulations were held invalid in a decision which indicated doubt about the right of the Treasury Department to deal fully with this problem by regulations. ${ }^{97}$

The 1954. Code embodies in the statute, with certain changes, the rules formerly prescribed by regulations ${ }^{98}$ along with the prior statutory provisions taxing trust income to the grantor because of a power to revoke or because trust income is or may be applied or held for the grantor's benefit. ${ }^{99}$ The statute prescribes five general tests for determining whether trust income paid to or accumulated for others is taxable to the grantor; if any one of these tests is met, the grantor is deemed the owner and the income is taxable to him regardless of, whether any one or more of the other tests is satisfied..$^{100}$

The statutory rules imposing these five tests are discussed below.

(1) Reversionary Interest.-The grantor is treated as the owner of any portion of a trust of which he has a reversionary interest in either the corpus or the income if the interest may reasonably be expected to take effect in possession or enjoyment within ten years from the transfer in trust of that portion or within an extension period of less than ten years. ${ }^{101}$

There is an exception to the ten-year rule which did not appear in the prior regulations. Trust income will not be taxable to the grantor to the extent that it is payable irrevocably for at least two years to a church or association or convention of churches, an educational organization or a hospital which qualifies for the exemption under the income tax laws. ${ }^{102}$ However, the report of the Senate Finance Committee ${ }^{103}$ sounds a warning note that this exception will not apply unless the income for the entire trust term must be paid to the "single

96. U.S. Treas. Reg. $118, \S 39.22$ (a) -21 (1953) ; U.S. Treas. Reg. 111, \$29.22(a) 21 (1943), as amended by T.D. 5488, 1946-1 CuM. BuLL. 19, and T.D. 5567, 1947-2 CuM. Bull. 9.

97. Commissioner v. Clark, 202 F.2d 94 (7th Cir. 1953).

98. $\S \S 671-675$. See SEN. Rep. No. 1622, 83d Cong., 2d Sess. 366 (1954).

99. $\$ \$ 676,677$. Int. Rev. Code of 1939, $\$ 166,53$ Srar. 68 (1939); Int. Rev. Code of 1939, \&167, as amended, 58 STAт. 51 (1944).

100. $\S 671$.

101. $\S 673(\mathrm{a})$.

102. $\$ 673$ (b). In Commissioner v. Clark, 202 F.2d 94 (7th Cir. 1953), it was held that the ten-year provision of the prior regulations was invalid and trust income was not taxable to the grantor where the trust was created prior to the issuance of the regulations and the income was payable for less than ten years to a nonprofit organization.

103. Sen. Rep. No. 1622, 83d Cong., 2d Sess. 366 (1954). 
specified beneficiary" and that it will not apply if the trustee has discretion to pay income to any one or more of several named charitable organizations.

As in the prior regulations, trust income will not be taxable to the grantor if it is payable to another person for life, even though such other person has a life expectancy of less than ten years. ${ }^{104}$ However, the Revenue Service ruled recently that trust income is taxable to the grantor where he has a reversionary interest in the corpus which will revert to his estate at death, if his life expectancy is less than ten years. ${ }^{105}$

(2) Power to Control Beneficial Enjoyment.-The general rule, as under the prior regulations, is that the grantor will be treated as the owner of a trust to the extent that the beneficial enjoyment of the corpus or income is subject to a power of disposition, exercisable by the grantor or a nonadverse party, or both, without the consent of an adverse party. ${ }^{106}$ As in the prior regulations, the statute enumerates a number of powers which are exceptions to the general rule and the existence of which will not result in taxing the income to the grantor. ${ }^{107}$

One of these exceptions introduces a new concept into the income tax statute. It provides that trust income shall not be taxable to the grantor because of the existence of a power to distribute, apportion or accumulate income or to pay out corpus to or for beneficiaries or a class of beneficiaries, if the power is exercisable solely by a trustee or trustees, none of whom is the grantor and not more than half of whom are "related or subordinate parties who are subservient to the wishes of the grantor." 108

The statute states that the term "related or subordinate party" means any nonadverse party who is the grantor's spouse living with the grantor; the grantor's father, mother, issue, brother or sister; an employee of the grantor; a corporation or any employee of a corporation in which the stock holdings of the grantor and the trust are significant from the viewpoint of voting control; or a subordinate employee of a corporation in which the grantor is an executive. ${ }^{100}$ A related or subordinate party "shall be presumed to be subservient to the grantor" with respect to powers conferred on him "unless such party is shown not to be subservient by a preponderance of the evidence." 110

104. $\$ 673(\mathrm{c})$.

105. Rev. Rul. 55-34, 1955-4 INT. Rev. BuLL. 9.

106. $\$ 674(\mathrm{a})$.

107. $\S 674(\mathrm{~b}),(\mathrm{c}),(\mathrm{d})$.

108. $\$ 674(\mathrm{c})$.

109. $\S 672(\mathrm{c})$.

110. Ibid. 
This is indeed an odd and puzzling provision. If a person such as the grantor's spouse, child or employee, who otherwise would be related or subordinate, has a beneficial and consequently an adverse interest in the trust, such person will not be considered related or subordinate. However, if such person has no adverse interest and consequently is a related or subordinate party, it must be determined further whether such person is also subservient to the grantor, and the burden is on the grantor to establish by a preponderance of the evidence that such person is not subservient.

What rules are to be applied in determining whether a husband or wife is subservient to the other? Is the determination to be made on the basis of physical prowess, dominating nature or size of pocketbook? The requirement that such trustees be subservient as well as related, in order to prevent the exception to the general rule from applying, was designed to make the exception more lenient to the grantor than would be true if the exception were made inapplicable merely because such trustees were related to the grantor. ${ }^{111}$ However, the difficulty of establishing by a preponderance of the evidence whether or not a related person is subservient to the grantor makes the provision of doubtful practical benefit.

(3) Administrative Powers Exercisable for the Grantor's Benefit.-The grantor is treated as the owner of a portion of the trust and is taxable on the income under this rule to the extent that powers may be exercised for the grantor's benefit by permitting him to deal with trust assets or borrow trust funds and to the extent that a power of administration is exercisable in a nonfiduciary capacity by any person without the approval of a person in a fiduciary capacity. ${ }^{112}$ The statute is violated and the income is taxed to the grantor to the extent that a person in a nonfiduciary capacity has a power (1) to vote or direct the voting of stock of a corporation in which the holdings of the grantor and the trust are significant from the viewpoint of voting control, or (2) to direct or veto investments to the extent that the trust funds consist of such stock, or (3) to the extent that there is a power to reacquire trust corpus by substituting other property.

The provisions relating to a power to vote stocks or direct investments are far from clear. If the grantor names himself trustee and reserves no express power to benefit himself through the voting of stocks or the investing of trust funds, his power to vote stocks or direct investments is necessarily exercisable in the interests of the trust bene-

111. See Sen. Rep. No. 1622, $83 d$ Cong., 2d Sess. 369 (1954).

112. $\S 675$. 
ficiaries and in a fiduciary capacity. Likewise, if the grantor is not named as trustee but reserves the power to vote stocks or direct investments, without reserving the right to exercise the power for his own benefit, the power will be exercisable by him in a fiduciary capacity. However, it may be that the statute intends to imply that if the trust assets include stocks of corporations in which the holdings of the grantor and the trust are significant from the viewpoint of voting control, the mere right of the grantor to vote the stocks or direct investments, whether or not as a trustee, is to be considered an administrative power exercisable in a nonfiduciary capacity. This provision of the statute requires clarification by the regulations.

(4) Power to Revoke.-The new Code continues the provisions of the prior statute ${ }^{113}$ treating the grantor as the owner of trust corpus and taxing him on the income to the extent that a power to revest in the grantor title to the trust fund is exercisable by the grantor or a nonadverse party or both. ${ }^{114}$ However, the new statute adds a provision that the grantor shall not be taxable on such income under this provision to the extent that the exercise of the power cannot affect the beneficial enjoyment of the income within ten years after the creation of the trust or an extension period, within the rule mentioned above relating to reversionary interests. ${ }^{115}$

(5) Income for the Benefit of the Grantor.-The new Code likewise continues the provisions of the prior statute ${ }^{116}$ that the grantor is taxable on trust income which is, or, in the discretion of the grantor or a nonadverse party or both, may be (1) distributed to the grantor; (2) held or accumulated for future distribution to the grantor or (3) applied to the payment of premiums on policies of insurance on the life of the grantor other than policies payable irrevocably for charitable purposes. $^{117}$ In keeping with other provisions taxing the grantor as owner, the new statute states that this provision shall not apply to a power to the extent that its exercise cannot affect the beneficial enjoyment within ten years after the transfer in trust or an extension period. ${ }^{118}$

The 1954 statute continues the prior provision ${ }^{119}$ that, income shall not be taxable to the grantor under this rule merely because such in-

113. Int. Rev. Code of 1939, §166, 53 Stat. 68 (1938).

114. $\S 676(\mathrm{a})$.

115. $\$ 676(\mathrm{~b})$.

116. Int. Rev. Code of 1939, $\S 167$, as amended, 58 Stat. 51 (1944).

117. $\$ 677(a)$.

118. Ibid.

119. Int. Rev. Code of $1939, \S 167(\mathrm{c})$, added by 58 Stat. 51 (1944). 
come in the discretion of another person, the trustee, or the grantor acting as trustee or co-trustee, may be applied or distributed for the support of a legal dependent of the grantor, except to the extent that the income is actually applied or distributed for such purpose. ${ }^{120}$ As in the prior statute, there is no provision relieving the grantor of tax on income where corpus may be applied for the support of a legal dependent and thus used for the grantor's benefit. The new statute provides, however, that where amounts are applied for the support of a legal dependent of the grantor from corpus or from income other than that for the taxable year, such amounts shall be deemed to be amounts paid or credited to the grantor and shall be taxed to him as a beneficiary of a second tier distribution. ${ }^{121}$

\section{Person Other Than Grantor Treated as Substantial Owener}

The rules taxing trust income to someone other than the grantor who does not receive the income, on the ground that he is to be considered the owner of the trust corpus or income, stem from Mallinckrodt v. Nunan, ${ }^{122}$ where trust income was held taxable to an individual who had broad powers over corpus and income, including the power at any time to terminate the trust and receive the corpus.

There was no provision of the prior statute which taxed trust income to a person other than the grantor as substantial owner, and the rules under the prior law were found in the regulations. ${ }^{123}$ The 1954 Code incorporates the rule of the prior regulations into the statute, with certain changes.

The statute ${ }^{124}$ states as the general rule that a person other than the grantor shall be treated as the owner and taxed on the income of any portion of a trust with respect to which:

(1) he has a power exercisable solely by himself to vest the corpus or the income in himself; or

(2) he has previously partially released or otherwise modified such a power and after the release or modification retains such control as would subject the grantor of a trust to tax as the owner under the rules applicable to the grantor.

120. $\S 677(\mathrm{~b})$.

121. Ibid. See text following note 43 supra.

122. 146 F.2d 1 (8th Cir.), cert. denied, 324 U.S. 871 (1945). See also Spies v. United States, 180 F.2d 336 (8th Cir. 1950); Emery v. Commissioner, 156 F.2d 728 (1st Cir.), cert. denied, 329 U.S. 772 (1946). But cf. Funk v. Commissioner, 185 F.2d 127 (3d Cir. 1950).

123. U.S. Treas. Reg. 118, $\$ 39.22$ (a) -22 (1953) ; U.S. Treas. Reg. 111, $\$ 29.22$ (a)-22, as added by T.D. 5488, 1946-1 Cum. BuLL. 19 (1946).

124. $\$ 678$. 
It is important to observe that in order for the substantial ownership rule to apply to a person other than the grantor, the prohibited power must be exercisable by such person alone. Unlike the grantor, such person will not be treated as the owner where the power is exercisable only in conjunction with a third person, whether or not having an adverse interest, or where the power is exercisable by the third person alone.

As an exception to the general rule, the person other than the grantor is not to be treated as owner because of a power to vest income in himself, if the grantor is otherwise treated as the owner under the rules relating to the grantor. ${ }^{125}$ The implication is that if a person other than the grantor has a power to vest corpus in himself, the trust income is to be taxed to him even though the grantor has a power or interest which otherwise could cause the income to be taxed to the grantor. The regulations should clarify this point.

The statute provides further that the general rule shall not apply to a power which enables such person, in the capacity of trustee or cotrustee, merely to apply the income of the trust to the support or maintenance of a legal dependent, except to the extent that the income is so applied. ${ }^{126}$ Although the statute does not so state, it implies that if such person in his individual capacity and not as a trustee has power to apply trust income for the support of a legal dependent, the income is taxable to him. Trust income which is used to discharge a legal obligation of the grantor has been held taxable to the grantor as beneficiary, ${ }^{127}$ and it has been held that a power in a trustee to apply trust income to discharge a legal obligation of the grantor is equivalent to a power to pay the income to the grantor. ${ }^{128}$ However, there have been no reported cases where the contention was made that those rules apply to trust income which is or may be applied to discharge the legal obligations of someone other than the grantor.

As in the case of the provisions relating to the grantor as owner, these provisions do not expressly relieve the person other than thet grantor of tax where he has the power as trustee or co-trustee to apply corpus for the support of a legal dependent. The statute states, however, that where such amounts are applied or distributed out of corpus or income other than that of the taxable year, such amounts are to be considered distributions of income and taxed to the holder of the power as a beneficiary of a second tier distribution. ${ }^{129}$

127. Douglas v. Willcuts, 296 U.S. 1 (1935) ; Helvering v. Schweitzer, 296 U.S.

551 (1935); Helvering v. Blumenthal, 296 U.S. 552 (1935).

128. Helvering v. Stuart, 317 U.S. 154 (1942).

129. $\S 678(c)$. See text following note 55 supra. 
It is provided further that the general rule taxing income to a person other than the grantor shall not apply to a power which has been renounced or disclaimed within a reasonable time after the holder of the power first became aware of its existence. ${ }^{130}$ The statute thus makes the same distinction between a release of a power and a disclaimer which is made by the estate and gift tax statutes relating to powers of appointment. ${ }^{131}$

\section{Income in Respect of Decedents}

The provisions relating to income in respect of decedents are found in Part II of Subchapter J, comprising Sections 691 and 692. The 1954 Code continues the provisions of the 1939 Code, enacted in $1942,{ }^{132}$ but adds provisions dealing with certain situations not covered by the prior law. As an aid to understanding the new provisions, it may be helpful to review the general provisions of the prior statute. ${ }^{133}$

The 1942 statute enacted provisions taxing to a decedent's estate or beneficiary items of income in respect of a decedent. The purpose of the statute was to grant relief from prior statutes ${ }^{134}$ which required the inclusion, in the final return of a cash-basis decedent, of all items of income accrued at death. ${ }^{135}$ The pre-1942 statute, as construed by the courts, was not limited to income accrued in a strict accounting. sense and resulted in some instances in the "bunching up" in a decedent's final return of large amounts of income which would be received over a period of several years after the decedent's death. ${ }^{136}$

Although the 1942 statute was aimed primarily at income accrued at death, the statute did not define "income in respect of a decedent," and the courts have construed the statute to be broad enough to tax to a decedent's estate or beneficiary all income earned by or attributable to the decedent during his lifetime whether or not accrued at the time of his death. For example, it has been held that a voluntary payment of

130. $\$ 678(\mathrm{~d})$.

131. $\$ 2041,2514$. See U.S. Treas. Reg. 105, $\$ 81.24$ (b) (3) (iii) (1942), as amended, T.D. 5283, 1943 CUM. BuLL. 1114; U.S. Treas. Reg. 108, $\$ 86.2$ (b) (5) (iii) (1943), added by T.D. 6077, 1954 InT. Rev. BulL. No. 30, at 22 (1954).

132. Int. Rev. Code of 1939, $\S 126$, added by 56 Stat. 831 (1942).

133. See 2 MERTENs, LAW of FEDERal INCOME Taxation $\$ 12.100$ (Supp. 1944) ; Craven, Taxation of Income of Decedents, 102 U. OF PA. L. REV. 185 (1953); Drye, The Taxation of a Decedent's Income, 8 TAX L. REv. 201 (1953). ment).

134. Int. Rev. Code of 1939, §42, 53 STAт. 24 (1939) (prior to 1942 amend-

135. Sen. Rep. No. 1622, 83d Cong., 2d Sess. 373 (1954) ; H.R. Rep. No. 2333, 77th Cong., 2d Sess. 83 (1942) ; SeN. Rep. No. 1631, 77th Cong., 2d Sess. 100 (1942).

136. See Helvering v. Enright, 312 U.S. 636 (1941). 
salary by an employer to the estate of a deceased employee for a period after death is taxable as income to the estate ${ }^{137}$ and that renewal commissions received by the estate of a deceased insurance agent are taxable as income to the estate. ${ }^{138}$

Items of income in respect of a decedent are taxable in the year in which received to the decedent's estate or to a legatee or other beneficiary acquiring from the decedent the right to receive such items. ${ }^{139}$ If the right to receive an item of income in respect of a decedent is transferred by the decedent's estate or other person acquiring such right from the decedent, the fair market value of such right at the time of the transfer is includible in the income of the estate or other person. ${ }^{140}$ The item of income is deemed to have been acquired by the decedent's estate or beneficiary in the same transaction in which it was acquired by the decedent and to have the same character to the estate as it would have in the hands of the decedent. ${ }^{141}$ Certain items of deductions and credits in respect of a decedent are allowed as deductions and credits in the year of payment to the estate or beneficiary obligated to make such payment. ${ }^{142}$

Items of income in respect of a decedent are ordinarily subject to estate tax as well as to income tax. In order to grant partial relief from double taxation, an income tax deduction is allowed for the federal estate tax, reduced by the credit for state death taxes, on the net income in respect of a decedent, that is, the excess of the gross income over the deductions reflected in the estate tax return. ${ }^{143}$ The amount of the estate tax is computed at the highest rates on such net income, that is, it is the difference between the amount of the estate tax with such income included and the amount of the estate tax with such income excluded. The estate tax is deductible by the estate or beneficiary proportionately each year in the ratio that the items of gross income in respect of a decedent received by the estate or beneficiary in that year bear to the total gross income included in the estate tax return.

The changes made by the 1954 Code are discussed below.

137. Bausch's Estate v. Commissioner, 186 F.2d 313 (2d Cir. 1951).

138. Estate of Thomas F. Remington, 9 T.C. 99 (1947) ; cf. Estate of Boyd C. Taylor, 17 T.C. 627 (1951), aff'd per curiam, 200 F.2d 561 (6th Cir. 1952).

139. $\$ 691$ (a) (1) (formerly Int. Rev. Code of 1939, $\S 126(a)(1)$, added by 56 Stat. 831 (1942)).

140 . $\$ 691$ (a) (2) (formerly Int. Rev. Code of 1939, $\$ 126(a)(2)$, added by 56 Stat. 831 (1942)).

141. $\$ 691$ (a) (3) (formerly Int. Rev. Code of 1939, $\S 126(a)(3)$, added by 56 Stat. 831 (1942)).

142. $\$ 691$ (b) (formerly Int. Rev. Code of 1939, $\$ 126(\mathrm{~b})$, added by 56 STat. $832(1942))$. (1942)).

143. §691(c) (formerly Int. Rev. Code of 1939, §126(c), added by 56 Stat. 832 


\section{Successive Decedents}

The prior statute ${ }^{144}$ provided that if a right to receive an item of income in respect of a decedent was transferred by the decedent's estate or other person who acquired such right from the decedent, the fair market value of the right at the time of the transfer was includible in the gross income of the estate or other person making the transfer. The regulations under the prior statute ${ }^{145}$ stated that if a right to receive income in respect of a decedent was disposed of, as by gift or bequest, by a person acquiring such right from the decedent, the fair market value of such right must be included in the income of that person. Yet the Internal Revenue Service ruled that where the widow of a deceased life insurance agent acquired from her husband the right to receive renewal commissions and she died before receiving the full amount of the commissions, the value of the uncollected portion was not includible in her final income tax return. ${ }^{146}$ Although approving the result, the Senate Finance Committee apparently considered the correctness of the ruling doubtful and thought that under the language of the statute and regulations the death of the widow resulted in a disposition of the right to receive the commissions and required the inclusion of the value of such right in the widow's final return. ${ }^{147}$ Therefore, the result of the ruling was written into the 1954 Code.

The 1954 statute provides that the transmission at death of a right to receive income in respect of a decedent shall not be deemed a transfer, ${ }^{148}$ so that the value of the uncollected portion shall not be taxed as income to the estate of the second or subsequent decedent prior to its collection. The uncollected portion is taxed to the estate, legatee or other beneficiary of the second or subsequent decedent only when it is received, ${ }^{149}$ and the estate or beneficiary of the second or subsequent decedent who receives the income is allowed a deduction for the estate tax imposed on the estate of the decedent from whom the right was acquired or any prior decedent in whose estate such right was taxed. ${ }^{\mathbf{1 5 0}}$

\section{Installment Obligations}

A person who sells property on an installment basis is permitted to report each year as income or capital gain the portion of the install-

144. Int. Rev. Code of $1939, \S 126$ (a) (2), added by 56 Stat. 831 (1942).

145. U.S. Treas. Reg. 118, $\$ 39.126(a)-1$ (f) (1953).

146. See 5 CCH 1952 FED. TAX REP. $\$ 6221$ (letter dated Dec. 27, 1951).

147. See Sev. Rep. No. 1622, 83d Cong., 2d Sess. 373 (1954).

148. $\S 691(\mathrm{a})(2)$.

149. $\S 691$ (a) (1). See Sen. Rep. No. 1622, 83d Cong., 2d Sess. 374 (1954).

150. $\S 691(\mathrm{c})(1)$. 
ment payment received in that year which the gross profit to be realized on the sale bears to the total sales contract price. ${ }^{151}$ The prior law provided that the death of an individual making an installment sale would accelerate the unrealized profit reflected in the uncollected installment obligations, ${ }^{162}$ so that the accelerated profit would be includible in his final income tax return. However, if a proper bond was filed by the decedent's representative, realization of the gain was postponed until the installment obligations were collected, and the gain was taxable to those entitled to receive the payments. ${ }^{153}$ In cases where a bond was given, there was no decision or ruling on whether the gain was income in respect of a decedent, and, therefore, it was not clear under the prior law whether the person required to report the gain after the decedent's death was entitled to a deduction for estate tax paid in the decedent's estate on the gain reflected in the unpaid installment obligations.

The 1954 statute eliminates the requirement of a bond and the requirement that the profit attributable to the uncollected portion be included in the decedent's final return ${ }^{154}$ and provides that gain on unpaid installment obligations shall be treated as income in respect of a decedent and taxed to the decedent's estate or beneficiary in years in which received. ${ }^{165}$ The result is that the estate or beneficiary will be entitled to a deduction for the estate tax paid on the value of the right to receive the gain reflected in the unpaid obligations.

\section{Income Distributions}

The Tax Court in Estate of Ralph R. Huesman ${ }^{156}$ and Rose J. Linde $^{157}$ held under the prior law that where a decedent's estate received an item of income in respect of a decedent and during the taxable year distributed such income to a legatee, the distribution was not deductible by the estate or taxable to the legatee, because it was a distribution of principal under state law. The soundness of the decisions is open to question. The circuit court affirmed the decision in the Huesman case ${ }^{158}$ on the ground that the legatee to which payment was made was entitled to receive nothing but principal and was not entitled to receive the amount so collected as income. The court refused

151. $\$ 453$.

152. Int. Rev. Code of 1939, §44(d), 53 Stat. 25 (1939).

153. Ibid.

154. See $\$ 453(d)(3)$.

155. $\$ 691$ (a) (4). See Sen. Rep. No. 1622, 83d Cong., 2d Sess. 374 (1954).

156. 16 T.C. 656 (1951), aff'd, 198 F.2d 133 (9th Cir. 1952). 1954).

157. 17 T.C. 584 (1951), aff'd in part and rev'd in part, 213 F.2d 1 (9th Cir.

158. Huesman's Estate v. Commissioner, 198 F.2d 133 (9th Cir. 1952). 
to say that if such an amount of income is distributed to a beneficiary entitled to receive that amount, the amount is not deductible by the estate and taxable to the beneficiary. In the Linde case, it was the Commissioner who contended before the Tax Court that the amount of income was deductible by the estate and taxable to the beneficiary; the circuit court did not pass on that point, because the Commissioner conceded the correctness of the Tax Court's decision. ${ }^{159}$

As has been pointed out, ${ }^{160}$ it is immaterial under the 1954 Code whether or not an amount distributed by an estate is income or principal under state law. With the exception of a specific bequest or devise, ${ }^{101}$ all distributions are treated as distributions of income in an amount not exceeding the distributable net income of the estate or trust for the taxable year. ${ }^{162}$ It follows then under the new law that an item of income in respect of a decedent which is received by the estate and distributed currently will be deductible by the estate and taxable to the beneficiary. ${ }^{163}$ A proportionate part of the deduction for the estate tax is allowed by the new law to a beneficiary to whom such income is distributed. ${ }^{164}$

\section{Joint and Survivor Annuities}

The prior statute relating to income in respect of a decedent ${ }^{165}$ did not refer to a joint and survivor annuity, and it was not clear under that law whether the survivor annuitant received an income tax deduction for any part of the estate tax paid on the value of the annuity in the estate of the deceased annuitant who furnished the consideration. The Internal Revenue Service ruled that annuities paid from retirement funds to widows or other beneficiaries of deceased employees were taxable under the provision of the income tax statute relating to annuities ${ }^{166}$ and not under the provision relating to income in respect of decedents and that no deduction was allowable for estate tax paid on the survivor's right to receive the taxable portion of the annuity. ${ }^{107}$ This ruling is questionable because such income, like other items of income, might well be taxable under both statutory provisions. It was ruled recently that the beneficiary of a deceased participant under a

159. Commissioner v. Linde, 213 F.2d 1, 7-8 (9th Cir. 1954).

160. See text following note 42 supra.

161. See text following note 64 supra.

162. $\$ 661(a), 662(a)$.

163. See SEN. Rep. No. 1622, 83d Cong., 2d Sess. 375 (1954).

164. $\S 691(\mathrm{c})$.

165. Int. Rev. Code of 1939, §126, added by 56 Stat. 831 (1942).

166. Int. Rev. Code of 1939, §22(b) (2), 53 Stat. 10 (1938).

167. See 4 CCH 1947 FEd. TAX REP. $\Uparrow 6132$ (letter dated Oct. 9, 1946). 
qualified employees' pension or profit sharing plan was entitled to deduct estate tax on the amount which would have been taxable to the decedent if he had lived. ${ }^{168}$

The prior statute taxed $3 \%$ of the cost of an annuity as income and excluded the balance of each year's payments until the total of the payments exceeded the cost of the annuity. ${ }^{169}$ The 1954 Code changes the method of taxing annuities by excluding from income each year an amount arrived at by dividing the cost of the annuity by the life expectancy of the annuitant or, in the case of a joint and survivor annuity, by the combined life expectancy of both annuitants. ${ }^{170}$ The balance of each year's payments is includible in income. The amount to be excluded each year remains the same after the death of the first annuitant.

If the first annuitant furnished all or a part of the consideration for the annuity, then, except for the portion purchased with funds furnished by the decedent's employer under a qualified pension, stock bonus or profit sharing plan, all or part of the value at the time of the decedent's death of the survivor's annuity is subject to estate tax in the decedent's estate. ${ }^{171}$ The 1954 statute relating to income in respect of a decedent allows to the survivor annuitant as a deduction each year a proportionate part of the estate tax on the estate of the deceased annuitant based on the portion of the annuity which will be includible in the survivor's income. No deduction is allowed for the amount of estate tax paid on the excludible portion of the annuity. ${ }^{172}$

The procedure to determine the amount of the deduction for the estate tax on the taxable portion of the annuity is rather complicated. The value of the annuity for estate tax purposes in the estate of the deceased annuitant is first determined. From this amount is deducted the total of the amounts to be excluded from income each year during the life expectancy of the survivor annuitant, and the difference is the date-of-death value of the taxable portion of the annuity. The estate tax on this taxable portion is then computed, and a proportionate part of such estate tax is allowed each year as a deduction over the life expectancy of the survivor, determined as of the date of the decedent's death. ${ }^{173}$

For example, assume that $A$ purchases for himself and $B$ a joint and survivor annuity of $\$ 1,000$ for which he pays $\$ 21,000$. Assume further that the joint expectancy of $A$ and $B$ is 30 years, so that the

168. Rev. Rul. 54-601, I.R.B. 1954-51, 27.

169. Int. Rev. Code of 1939, $\$ 22$ (b) (2), 53 Stat. 10 (1938).

170. $\$ 72(\mathrm{~b}),(\mathrm{c})$.

171. $\$ 2039$.

172. $\S 691(d)$.

173. See Sen. Rep. No. 1622, 83d Cong., 2d Sess. 375-76 (1954). 
amount to be excluded from gross income each year throughout the expectancy of $A$ and $B$ is $\$ 21,000 / 30$ or $\$ 700$. Assume that $A$ dies and that on his death the annuity has a value of $\$ 12,000$ and that there remain 15 years of the combined expectancy of $A$ and $B$, so that the total of the annual exclusions over such period will be $15 \times \$ 700$ or $\$ 10,500$. No deduction will be allowed for the estate tax on the excludible portion of $\$ 10,500$. However, a deduction will be allowed to $B$ for estate tax in $A$ 's estate on $\$ 1,500$, the difference between the total value of $\$ 12,000$ and the total exclusions of $\$ 10,500$. If, for example, the highest estate tax rate in $A^{\prime} s$ estate is $30 \%$, the deduction for estate tax will be $30 \%$ of $\$ 1,500$ or $\$ 450$, which will be spread over the remaining expectancy of 15 years, so that $B$ will be entitled to a deduction each year of $\$ 30$, in addition to the exclusion of $\$ 700$.

Assume in this example that because a portion of the consideration for the annuity was furnished by $B$, only one-half of the value of the annuity is includible in $A$ 's estate. The deduction for estate tax allowable to $B$ will be the tax on one-half of $\$ 1,500$, or $\$ 750$, which tax will be $30 \%$ of that amount or $\$ 225$. In that case, $B$ will be entitled to a deduction of $\$ 15$ a year over the remaining expectancy of 15 years.

The statute is not clear on one point. The statutory provision dealing with taxation of joint and survivor annuities ${ }^{174}$ indicates that the exclusion factor is to be based on the combined expectancy of two or more joint annuitants and that the exclusion factor is to remain the same after the death of the first annuitant..75 However, the provision dealing with income in respect of decedents ${ }^{176}$ indicates. that after the death of the annuitant who furnished the consideration, the amount to be excluded each year from the income of a survivor is to be based on the survivor's remaining expectancy, which may be quite different from the remaining period of a combined expectancy. This point should be clarified by the regulations.

\section{Payments to Successor in Interest of a Deceased Partner}

Certain payments made by a partnership to a successor in interest of a deceased partner, in liquidation of the decedent's interest, are treated by the 1954 Code as income in respect of a decedent. ${ }^{177}$ Payments which are so treated are (1) payments made as a distributive share of partnership income where the amount is based on partnership income and (2) guaranteed payments determined without regard to

174. $\S 72$.

175. See Sen. Rep. No. 1622, 83d Cong., 2d Sess. 175 (1954).

176. $\$ 691(\mathrm{~d})(2)(\mathrm{A})$.

177. $\$ 691(\mathrm{e}), 736,753$. 
income of the partnership for services or use of capital. ${ }^{178}$ However, the payments so treated as income to such successor in interest do not include payments made by the partnership in exchange for the deceased partner's interest in partnership property other than unrealized receivables and good will, and they do not include payments made for good will if the partnership agreement provides for a payment for good will. ${ }^{179}$

The treatment as income in respect of a decedent of such payments to the successor in interest of a deceased partner means that if any amount is subject to estate tax in the deceased partner's estate on account of the value of the right to receive such payments, the deceased partner's estate or other successor in interest will be entitled to an income tax deduction for the estate tax paid on such amount. If the payments are made merely on account of a contractual right to participate in partnership earnings for a period after the decedent's death and are not made in payment for the deceased partner's interest in partnership property, there should be no estate tax on such right. ${ }^{180}$ However, a payment on account of a right to income which had accrued at the time of the decedent's death or a right to receive guaranteed payments, or on account of the decedent's interest in unrealized receivables or good will would be subject to estate tax to the extent of the value of the right or interest for which such payments are made.

\section{Employee's Stock Option}

There was no provision of the prior statute which dealt with the realization of income by the estate or a beneficiary of a deceased employee on the exercise of an employee's restricted stock option or the disposition of the stock, ${ }^{181}$ and the tax consequences in such cases were uncertain. ${ }^{182}$ The 1954 Code provides that if a restricted stock option is exercised subsequent to the death of the employee by his estate or beneficiary, the transaction is to be treated for tax purposes in the same way as if the exercise had been made by the decedent. ${ }^{183}$ If an amount is required to be included in the gross income of the estate or beneficiary on account of the stock option, a deduction is allowed for the

178. $\$ 736(a)$.

179. \$736(b). See Sen. Rep. No. 1622, 83d Cong., 2d Sess. $405-06$ (1954).

180. See Bull v. United States, 295 U.S. 247, 254 (1935) ; Charles F. Coates, 7 T.C. 125, 131, 132 (1946) ; Richard P. Hallowell, 2nd, 39 B.T.A. 50, 55 (1939). But cf. McClennen v. Commissioner, 131 F.2d 165 (1st Cir. 1942).

181. See Int. Rev. Code of 1939, $\$ 130$ A, added by 58 Stat. 48 (1944).

182. See Sen. Rep. No. 1622, 83d Cong., 2d Sess. 296 (1954) ; Drye, The Taxation of a Decedent's Income, 8 TAX L. REv. 201, 212 (1953).

183. §421. 
estate tax attributable to the inclusion in the taxable estate of the deceased employee of the net value for estate tax purposes of the restricted stock option. For this purpose, the deduction is determined as if the option acquired by the deceased employee was an item of gross income in respect of a decedent. ${ }^{184}$

\section{Taxpayer Dying in Armed Forces}

The 1954 Code in Section 692 continues the provision of the prior statute ${ }^{185}$ which cancels income taxes of a taxpayer dying in the armed forces. The statute states that if an individual dies during an induction period in active service as a member of the armed forces of the United States, and his death occurred while serving in a combat zone or as a result of wounds, disease or injury incurred while so serving, no income tax shall be imposed on such individual for the taxable year of death or any prior year ending on or after the first day of his service after June 24,1950 . In addition, the statute cancels any unpaid liability of such individual for income tax for prior taxable years. The provisions of the prior law were applicable only where the taxpayer died prior to January 1,1955 . There is no specific termination date under the new statute.

184. $\S 421(\mathrm{~d})(6)$.

185. Int. Rev. Code of 1939, $\S 154$, added by 65 Stat. 507 (1951), as amended, 67 Stat. 616 (1953). 


\title{
University of Pennsylvania Law Review
}

\author{
Formerly \\ American Law Register \\ FOUNDED 1852
}

Member, National Association of Law Reviews

BOARD OF EDITORS

JoSEPH V. REAPH, JR., Editor-in-Chief

Robert L. Kendall, JR., Managing Editor

David J. Kaufman, Note Editor Joel C. Coleman, Case Editor

Hendy S. Rute, JR, Note Editor James M. RICeardson, Case Editor

MERVIN M. WIIf, Article Editor

JACR VAN BAALEN, Research Editor and Book Review Editor

ROBERT M. BECKMAaN

W. Thomas BerrIMAN

JoHN L. BOYLE

MattheW J. Broderick

Walter J. Colins, Jr.

Thomas A. EVERLY, JR.

STEPHEN M. FELDMaN

Henry B. FitzPatrick, JR.

RICEARd H. Floum

PaUl D. GUTH

David C. Harrison

J. BARTON HarRISON

Richard S. HoFraranN

DOLORES KORMAN
Arthur W. LeIboLd, JR.

Peter J. Liacouras

Richard I. MCMathoN

George J. MrLIER

ARTHUR H. Moss

HARRIS OMINSKY

Curtis R. Reitz

S. WHITE RHYNE, JR.

ALAN M. RUBEN

CARL W. SchNeIDER

Albert S. SHaw, JR.

William F. Sullivan, JR.

Alfred T. Williams, JR.

GUYLA F. WOODWARD

EdWard W. Brennan, EsQ., Business Manager

Correspondence should be directed to departmental editors. 